\title{
The Role of School Foodservice Personnel in Nutrition Education: Challenges and Opportunities at U.S. Elementary Schools
}

\author{
Thushanthi Perera ${ }^{1}$, Simone Frei ${ }^{1}$, Balz Frei ${ }^{1}$, Siew Sun Wong ${ }^{2}$ and Gerd Bobe ${ }^{1^{*}}$ \\ ${ }^{1}$ Linus Pauling Institute, Oregon State University, Corvallis, Oregon, USA \\ ${ }^{2}$ College of Family \& Community Health, Oregon State University Corvallis, Oregon, USA
}

"Corresponding author: Gerd Bobe, Linus Pauling Institute, Oregon State University, 307 Linus Pauling Science Center, Corvallis, Oregon, 97331, USA, Tel: (541) 737-1898; E-mail: gerd.bobe@oregonstate.edu

Rec date: Aug 18, 2015; Acc date: Aug 27, 2015; Pub date: Aug 29, 2015

Copyright: ( 2015 Perera T, et al. This is an open-access article distributed under the terms of the Creative Commons Attribution License, which permits unrestricted use, distribution, and reproduction in any medium, provided the original author and source are credited.

\begin{abstract}
The food environment at school plays an important role in promoting healthy food choices in students. In our previous study, classroom teachers were concerned about some of the meal options offered at their school cafeteria and wanted a school cafeteria component as part of a successful nutrition education program. In response, our first objective was to evaluate the nutritional quality of school meals at Oregon elementary schools. We learned that unless students ate the recommended amount of fruits and vegetables from the salad bar, school menus did not meet the nutrition standards for fruits (99\%) and vegetables (100\%). As the second objective, we asked Oregon elementary school foodservice personnel (SFP) in a cross-sectional, anonymous mail survey if and how they should be involved in nutrition education programs. Of the 59 SFP who responded, all perceived that nutrition education in elementary schools is somewhat to very important and $76 \%$ perceived that they should be involved in a successful nutrition education program. They were interested in nutrition education training $(75 \%)$ but noted multiple barriers for incorporating the school cafeteria into nutrition education programs, the primary were cost $(66 \%)$, time $(58 \%)$, and potential teaching commitments. SFP wanted to be involved in nutrition education through nutrition posters in the cafeteria (58\%) and new recipes and food items (56\%). In conclusion, SFP are highly motivated to participate in nutrition education programs through activities in the school cafeteria that do not involve teaching. Renewed focus should be on developing and implementing nutrition education programs that provide SFP with training and new recipes and food items that are nutritious, affordable, easy and quick to prepare, and appealing to students so that nutrition information delivered in the classroom can be reinforced in the school cafeteria.
\end{abstract}

Keywords: Childhood obesity; Curriculum; Elementary school foodservice personnel; Food environment; Nutrition education

\section{Acronyms and Abbreviations}

AI: Adequate Intake; AMDR: Acceptable Macronutrient Distribution Range; BKFS: Block Kids Food Screener; DFE: Dietary Folate Equivalents; DG: Dietary Guidelines; EAR: Estimated Adequate Requirements; FFQ: Food Frequency Questionnaire; IOM: Institute of Medicine; NSLP: National School Lunch Program; RDA: Recommended Dietary Allowance; SBP: School Breakfast Program; SEM: Standard Error Of Mean; SFP: School Foodservice Personnel; SNDA: School Nutrition Dietary Assessment Study; SMI: School Meals Initiative; RAE: Retinol Activity Equivalents; STD: Standard Deviation; USDA: U.S. Department of Agriculture; UL: Tolerable Upper Intake Level

\section{Introduction}

The school cafeteria can be an important component of successful nutrition education programs by providing healthy and nutritious meals and thereby reinforcing nutrition information taught in the classroom [1]. Nutrient recommendations and guidelines have been established and updated by experts and government officials for children, stratified by gender and age [2,3]. Based on 1989 Recommended Dietary Allowances (RDA) and 1995 Dietary Guidelines for Americans, the U.S. Department of Agriculture
(USDA) specified in 1995 nutrition standards (School Meals Initiative (SMI) Standards) for the National School Lunch Program (NSLP) and School Breakfast Program (SBP), which are federal meal assistance programs for schools with the goal to provide healthy and nutritious meals to school-aged children [4]. Based on the 2005 and then 2010 Dietary Guidelines for Americans, the nutrient and meal pattern standards were updated and implemented starting July 2012 [5].

Although many school menus met federal requirements, most elementary school children consumed diets insufficient in fiber, calcium, potassium, and vitamin $\mathrm{E}$ and excessive in sodium, total fat, and saturated fat based on the last nationwide survey in 2011-2012 [6]. The primary reason was that fruits and vegetables offered to children as part of their school menus often ended up as waste $[7,8]$. We observed similar results in Oregon elementary school children [9]. Moreover, classroom teachers were concerned about some of the food choices offered at their school cafeteria [10].

Besides providing nutritious meals, school foodservice personnel (SFP) can be involved in nutrition education programs by providing nutrition information and experiential learning activities, including nutrition education materials, kitchen tours, food for classroom activities, guest presentations in classrooms, tasting parties, nutrition information for parents, and/or cooking demonstrations [11,12]. The role of SFP in nutrition education programs is not well defined. When asked, elementary school classroom teachers wanted a school cafeteria component as part of an effective and successful nutrition education 
program so that the school food environment would reflect what was taught in the classroom [10].

Given this context, the first objective is to assess the nutritional quality of breakfast and lunch meals in Oregon elementary schools (School menu survey). The second objective is to identify facilitators, barriers, and preferences of SFP's involvement in nutrition education programs (SFP survey). To our knowledge, this has not been evaluated.

\section{Materials and Methods}

\section{School menu survey}

The Block Kids Food Screener (BKFS) was used to assess the nutrition quality of breakfast and lunch meals in Oregon elementary schools (environmental assessment). The BKFS has been described and validated for 2-17 year-old U.S. children [13,14]. In short, it is a 41-item, two-page food frequency questionnaire (FFQ) that asks for frequency (six categories from none to every day) and quantity of dietary intakes (four categories) of the most commonly consumed food items by children. Between April and November 2011, we collected breakfast and lunch menus that were offered in public elementary schools of 12 school districts across Oregon. The study staff filled out 25 BKFS per school district as follows: For breakfast, it was assumed that children would eat every day the offered breakfast cereal with low fat $1 \%$ milk and would consume fruit or fruit juice, which were offered on alternate days. The school lunch offered three menu choices; one menu choice was chosen randomly for lunch and another for dinner. It was assumed that children drank low fat $1 \%$ milk with breakfast, lunch, and dinner. Since children did not consume school meals on the weekend, food consumption for Saturday and Sunday were based on menu items offered during the week; we chose arbitrarily Wednesdays' and Thursdays' menu choices, respectively. The completed BKFS were analyzed by Nutrition Quest (Berkeley, California) for food servings and nutrient intake. Food codes identified in the food list development of BKFS were linked to the USDA's Food and Nutrient Database for Dietary Studies and the USDA's My Pyramid Equivalents Data Base to calculate nutrient intakes. The calculated nutrient intakes were calorie-adjusted and expressed per 1,000 kcal. To calculate the proportion of school menus not meeting recommendations, calorie-adjusted intakes were multiplied by the estimated energy requirements for elementary school children [2] and then compared to the 2010 Dietary Guidelines and recommendations published by the U.S. Department of Agriculture and U.S. Department of Health and Human Services [3] as well as the previous SMI Standards [5]. For calculating food group consumption, we included salad bar options three different ways: - Salad Bar excluded intake from the salad bar; + Salad Bar assumed that students consume 1 cup of fruits offered at the salad bar at breakfast and 0.5 cup of fruit and 1 cup of vegetables offered at the salad bar each at lunch and dinner; + Some Salad Bar was based on previously reported observations that $73 \%$ of vegetables and $47 \%$ of fruits on plates were not consumed [8].

\section{SFP survey}

The study was reviewed and approved by the Oregon State University Institutional Review Board (IRB protocol number 4953; "Childhood Nutrition and Exercise in Elementary Schools"). After receiving written approval from the school district foodservice departments (we had mailed all Oregon foodservice departments information about the study), packages that contained anonymous mail surveys in English and paper format, alternative consent forms, and stamped return envelopes were mailed to 12 food service departments across Oregon in November 2011. Of the 94 contacted SFP, 59 returned the completed survey by December 2011 (63\% response rate). The participating foodservice departments covered a representative sample of Oregon schools, as they covered urban, semirural, and rural districts.

To identify facilitators, barriers, and preferences of SFP's involvement in nutrition education programs, we developed a onepage questionnaire. The questions were formulated to assess the following constructs: facilitators (importance, concern, knowledge, interest, impact, and responsibility for a total of 7 questions), barriers (at school, personal, at home, and for training for a total of 4 questions), and preferences (1 question). The scales for most facilitators were five-level Likert-type scales. Questions for barriers and preferences were designed to be open-ended; some options were given to provide a general direction of the question; however, respondents could fill in their personal responses under "others". These questionnaires were not pretested for their validity. The survey was in paper format, English only, and anonymous. To maintain confidentiality, we did not ask questions about the student population (race, ethnicity, social economic status), training background of the responding SFP (training in nutrition, culinary arts, or health science), and how SFP personnel was already involved in nutrition education. The primary theoretical framework for the survey was the health belief model, as SFP are mostly guided by rational decision making [15]. To account for environmental and social factors and the complexity of the task of improving food choices of elementary school students, we included constructs from the social-ecological model and the social cognitive theory [15].

\section{Statistical analysis}

Statistical analyses were performed using SAS version 9.2 software [16]. We used Fisher's exact test to compare responses of supervisors and managers (managers) with responses of other SFP (employees). All statistical tests were two-sided. Statistical significance was declared at $\mathrm{P} \leq 0.05$.

\section{Results}

\section{School menu survey}

In 2011, the fruits and vegetables offered at the salad and fruit bar played an important role in meeting the federal school meal pattern standards, which had to be implemented by 2012 to receive federal assistance (Table 1). Unless students ate from the salad bar, 1 cup of fruit at breakfast and 1 cup of vegetables and 0.5 cup of fruit at lunch, most school menus did not meet the meal pattern standards for fruits (99\%), vegetables (100\%), legumes (92\%), and other vegetables (100\%) for the following year. These estimates did not change substantially when accounting for the amounts of fruits and vegetables consumed from the salad bar according to Cohen et al. [8]. The menu options offered were familiar to and popular with children and can be found commonly in Kid's meals menus, such as hotdogs, spaghetti with meat balls, peanut butter and jelly sandwiches, ham and cheese sandwiches, pizza, hamburgers, chicken nuggets, tacos, and nachos. The variety of offered menu options over a month was limited. 
Citation: Perera T, Frei S, Frei B, Wong SS, Bobe G (2015) The Role of School Foodservice Personnel in Nutrition Education: Challenges and Opportunities at U.S. Elementary Schools. J Health Edu Res Dev 3: 133. doi:10.4172/2380-5439.1000133

Page 3 of 8

\begin{tabular}{|l|l|l|l|l|l|}
\hline Meal Pattern & Units & $\begin{array}{l}\text { Salad } \\
\text { Bar }^{\mathrm{a}}\end{array}$ & $\begin{array}{l}+ \text { Salad } \\
\text { Bar }^{\mathrm{a}}\end{array}$ & $\begin{array}{l}\text { Some } \\
\text { Salad Bar }\end{array}$ & $\begin{array}{l}\text { Standard } \\
\mathbf{s}^{\mathrm{b}}\end{array}$ \\
\hline \multicolumn{5}{|l|}{ Mean \pm STD } \\
\hline Fruit & Cups/wk & $5.3 \pm 2.7$ & $12.3 \pm 2.7$ & $9.7 \pm 2.7$ & 14.0 \\
\hline Vegetables & Cups/wk & $3.5 \pm 1.5$ & $17.5 \pm 1.5$ & $5.0 \pm 1.5$ & 10.5 \\
\hline Potatoes & Cups/wk & $0.9 \pm 0.8$ & $0.9 \pm 0.8$ & $0.9 \pm 0.8$ & 1.4 \\
\hline Legumes & Cups/wk & $0.4 \pm 0.5$ & $1.1 \pm 0.5$ & $0.9 \pm 0.5$ & 1.4 \\
\hline $\begin{array}{l}\text { Other } \\
\text { Vegetables }\end{array}$ & Cups/wk & $3.1 \pm 1.4$ & $14.3 \pm 1.4$ & $4.3 \pm 1.4$ & 7.7 \\
\hline Not Meeting Guidelines & $\%$ of School Menus \pm SEM & \\
\hline Fruit & Cups/wk & $99 \pm 1$ & $74 \pm 3$ & $92 \pm 1$ & - \\
\hline Vegetables & Cups/wk & $100 \pm 0$ & $0 \pm 0$ & $100 \pm 0$ & - \\
\hline Potatoes & Cups/wk & $74 \pm 3$ & $74 \pm 3$ & $74 \pm 3$ & - \\
\hline Legumes & Cups/wk & $92 \pm 2$ & $0 \pm 0$ & $92 \pm 2$ & - \\
\hline $\begin{array}{l}\text { Other } \\
\text { Vegetables }\end{array}$ & Cups/wk & $100 \pm 0$ & $0 \pm 0$ & $98 \pm 1$ & - \\
\hline
\end{tabular}

Table 1: Meal Patterns Offered at Elementary Schools in 12 Oregon school districts in $2011(\mathrm{n}=299)$. ${ }^{\mathrm{a}}$-Salad Bar excludes intake from salad bar; + Salad bar estimates that students consume 1 cup of fruit at breakfast and 0.5 cup of fruit each at lunch and dinner and consume 1 cup of vegetables each at lunch and dinner; + Some Salad Bar accounts for previously reported intake from salad bar [8] ${ }^{\mathrm{b}}$-Using the nutrition standards for the 2012 NSLP and SBP [5], guidelines were adjusted per 7-day week.

In 2011, Oregon elementary school cafeteria menus met the 2010 Dietary Guidelines for most macronutrients and micronutrients for elementary school-aged children (Table 2). The exceptions were dietary fiber ( $94 \%$ of school meals), linoleic acid (100\%), linolenic acid (100\%), potassium (100\%), vitamin E (100\%), and vitamin K $(94 \%)$, which were all below dietary guidelines, and saturated fat (97\%) and sodium $(100 \%)$, which were above dietary guidelines [3] unless we also accounted for food items offered at the salad bar. In addition, we examined whether the menus provided sufficient nutrients based on the previous SMI standards [4]. All school menus excluding the salad bar met standards for calcium and protein. A majority of school menus were too high in saturated fat (97\%) and total fat (75\%); $34 \%$, $6 \%$, and $3 \%$ of school menus were below policies for vitamin C, iron, and vitamin A, respectively.

\begin{tabular}{|l|l|l|l|l|}
\hline Nutrient & \multicolumn{2}{|l|}{$\begin{array}{l}\text { Average } \\
\text { Content }\end{array}$} & Menu Nutrient & $\begin{array}{l}\text { Menus Not Meeting } \\
\text { Guidelines }\end{array}$ \\
\cline { 2 - 5 } & Units & Mean \pm STD & $\begin{array}{l}\text { Guidelin } \\
\text { es }\end{array}$ & $\begin{array}{l}\text { \% of Menus } \pm \\
\text { STD }, \mathrm{b},\end{array}$ \\
\hline
\end{tabular}

\section{Macronutrients}

\begin{tabular}{|l|l|l|l|l|}
\hline Protein & $\mathrm{g} / 1,000 \mathrm{kcal}$ & $56 \pm 4$ & $<\mathrm{RDA}$ & $0 \pm 0$ \\
\hline Carbohydrate & $\mathrm{g} / 1,000 \mathrm{kcal}$ & $113 \pm 11$ & $<\mathrm{RDA}$ & $2 \pm 14$ \\
\hline Fiber & $\mathrm{g} / 1,000 \mathrm{kcal}$ & $8.8 \pm 2.1$ & $<\mathrm{OOM}$ & $94 \pm 24$ \\
\hline Total Fat & $\mathrm{g} / 1,000 \mathrm{kcal}$ & $35.9 \pm 3.9$ & $>$ AMDR & $17 \pm 38$ \\
\hline
\end{tabular}

\begin{tabular}{|c|c|c|c|c|}
\hline Saturated Fat & $\mathrm{g} / 1,000 \mathrm{kcal}$ & $14.0 \pm 1.6$ & $>D G$ & $97 \pm 17$ \\
\hline Linoleic Acid & $\mathrm{mg} / 1,000 \mathrm{kcal}$ & $4.21 \pm 0.49$ & $<\mathrm{Al}$ & $100 \pm 0$ \\
\hline Linolenic Acid & $\mathrm{mg} / 1,000 \mathrm{kcal}$ & $0.41 \pm 0.05$ & $<\mathrm{Al}$ & $100 \pm 0$ \\
\hline Cholesterol & $\mathrm{mg} / 1,000 \mathrm{kcal}$ & $115 \pm 27$ & $>D G$ & $4 \pm 20$ \\
\hline \multicolumn{5}{|l|}{ Minerals } \\
\hline Calcium & $\mathrm{mg} / 1,000 \mathrm{kcal}$ & $1065 \pm 108$ & $<\mathrm{RDA}$ & $0 \pm 0$ \\
\hline Phosphorus & $\mathrm{mg} / 1,000 \mathrm{kcal}$ & $1073 \pm 80$ & $<$ RDA & $0 \pm 0$ \\
\hline Magnesium & $\mathrm{mg} / 1,000 \mathrm{kcal}$ & $172 \pm 14$ & $<\mathrm{RDA}$ & $0 \pm 0$ \\
\hline Iron & $\mathrm{mg} / 1,000 \mathrm{kcal}$ & $11.9 \pm 2.3$ & $<\mathrm{RDA}$ & $0 \pm 0$ \\
\hline Zinc & $\mathrm{mg} / 1,000 \mathrm{kcal}$ & $9.50 \pm 0.86$ & $<$ RDA & $0 \pm 0$ \\
\hline Copper & $\mu \mathrm{g} / 1,000 \mathrm{kcal}$ & $487 \pm 33$ & $<\mathrm{RDA}$ & $0 \pm 0$ \\
\hline Selenium & $\mu \mathrm{g} / 1,000 \mathrm{kcal}$ & $64.9 \pm .3$ & $<\mathrm{RDA}$ & $0 \pm 0$ \\
\hline Potassium & $\mathrm{mg} / 1,000 \mathrm{kcal}$ & $1786 \pm 137$ & $<\mathrm{Al}$ & $100 \pm 0$ \\
\hline Sodium & $\mathrm{mg} / 1,000 \mathrm{kcal}$ & $1641 \pm 131$ & $>U L$ & $100 \pm 0$ \\
\hline \multicolumn{5}{|l|}{ Vitamins } \\
\hline Vitamin A & $\begin{array}{l}\mu \mathrm{g} R A E / 1,000 \\
\text { kcal }\end{array}$ & $553 \pm 65$ & $<\mathrm{RDA}$ & $0 \pm 0$ \\
\hline Vitamin C & $\mathrm{mg} / 1,000 \mathrm{kcal}$ & $39 \pm 16$ & $<\mathrm{RDA}$ & $12 \pm 32$ \\
\hline Vitamin $\mathrm{E}$ & $\mathrm{mg} / 1,000 \mathrm{kcal}$ & $2.32 \pm 0.27$ & $<\mathrm{RDA}$ & $100 \pm 0$ \\
\hline Thiamin & $\mathrm{mg} / 1,000 \mathrm{kcal}$ & $0.98 \pm 0.13$ & $<\mathrm{RDA}$ & $0 \pm 0$ \\
\hline Riboflavin & $\mathrm{mg} / 1,000 \mathrm{kcal}$ & $1.98 \pm 0.19$ & $<$ RDA & $0 \pm 0$ \\
\hline Niacin & $\mathrm{mg} / 1,000 \mathrm{kcal}$ & $12.5 \pm 1.46$ & $<$ RDA & $0 \pm 0$ \\
\hline Vitamin B6 & $\mathrm{mg} / 1,000 \mathrm{kcal}$ & $1.25 \pm 0.15$ & $<\mathrm{RDA}$ & $0 \pm 0$ \\
\hline Folate & $\begin{array}{l}\mu \mathrm{g} D F E / 1,000 \\
\text { kcal }\end{array}$ & $407 \pm 79$ & $<\mathrm{RDA}$ & $<1 \pm 0$ \\
\hline Vitamin B12 & $\mu \mathrm{g} / 1,000 \mathrm{kcal}$ & $5.25 \pm 0.60$ & $<\mathrm{RDA}$ & $0 \pm 0$ \\
\hline Vitamin $\mathrm{K}$ & $\mu \mathrm{g} / 1,000 \mathrm{kcal}$ & $18.1 \pm 8.2$ & $<$ RDA & $94 \pm 23$ \\
\hline
\end{tabular}

Table 2: Nutrient content of elementary school meals (excluding the salad bar) in 12 Oregon school districts in 2011 ( $\mathrm{N}=299)$. RDA: recommended dietary allowance; IOM: Institute of Medicine; AMDR: acceptable macronutrient distribution range; DG: dietary guidelines; EAR: estimated adequate requirements; AI: adequate intake; UL: tolerable upper intake level; RAE: retinol activity equivalents; DFE: dietary folate equivalents. ${ }^{\mathrm{a}} \%$ of menus meeting 2010 Dietary Guidelines [3] was calculated by comparing the recommended with the estimated nutrient consumption per $1,000 \mathrm{kcal}$ or \% calories [2]. bThe SMI standards specified that school meals should follow RDA's for protein, calcium, iron, vitamin $\mathrm{A}$, and vitamin $\mathrm{C}$ and provide less than $10 \%$ of energy from saturated fat and no more than $30 \%$ of energy from fat [4]. The SMI standards were achieved for all menus for calcium and protein. Inadequacies were observed for saturated fat ( $97 \%$ of menus), total fat (75\%), vitamin C (34\%), iron (6\% of menus), and vitamin $\mathrm{A}(3 \%)$. 
Page 4 of 8

\section{SFP survey}

Responding SFP included 2 supervisors, 26 managers, 22 cooks, 5 assistants, 1 food service specialist, 1 kitchen specialist, 1 dishwasher, and 1 person who did not specify his/her title. We combined responses of supervisors and managers as one group (managers; $n=28$ ) and responses of other SFP as another group (employees; $n=31$ ). All SFP perceived nutrition education in elementary schools as somewhat to very important (Table 3$)$. Nearly all SFP $(98 \%)$ were somewhat to very concerned about childhood nutrition, rated their knowledge as average to proficient $(95 \%)$, and were somewhat to very interested in learning more about childhood nutrition (88\%). SFP perceived that nutrition education in elementary schools could improve students' food choices long-term $(61 \%)$ or at least short-term (15\%), and that they should be involved in a successful nutrition education program $(76 \%)$.

\section{Facilitator Responses (Values are \% followed by number of responses in $\mathbf{s}$ parenthesis) ${ }^{\mathrm{a}}$}

Importance: How important is nutrition education in elementary schools?

\begin{tabular}{|l|l|l|l|l|l|l|}
\hline Very & Important & $\begin{array}{l}\text { Somewha } \\
\mathrm{t}\end{array}$ & Little & Not & $\begin{array}{l}\text { Not } \\
\text { sure }\end{array}$ & $\begin{array}{l}\text { No } \\
\text { answer }\end{array}$ \\
\hline $\begin{array}{l}63 \% \\
(37)\end{array}$ & $34 \%(20)$ & $3 \%(2)$ & $0 \%(0)$ & $0 \%(0)$ & $0 \%(0)$ & $0 \%(0)$ \\
\hline
\end{tabular}

Concern: Are you concerned about childhood nutrition?

\begin{tabular}{|l|l|l|l|l|l|l|}
\hline Very & $\begin{array}{l}\text { Concerne } \\
\mathrm{d}\end{array}$ & $\begin{array}{l}\text { Somewha } \\
\mathrm{t}\end{array}$ & Little & Not & $\begin{array}{l}\text { Not } \\
\text { sure }\end{array}$ & $\begin{array}{l}\text { No } \\
\text { answer }\end{array}$ \\
\hline $\begin{array}{l}39 \% \\
(23)\end{array}$ & $42 \%(25)$ & $17 \%(10)$ & $2 \%(1)$ & $0 \%(0)$ & $0 \%(0)$ & $0 \%(0)$ \\
\hline
\end{tabular}

Knowledge: How would you rate your knowledge on childhood nutrition?

\begin{tabular}{|l|l|l|l|l|l|l|}
\hline High & Average & Proficient & Little & No & $\begin{array}{l}\text { Not } \\
\text { sure }\end{array}$ & $\begin{array}{l}\text { No } \\
\text { answer }\end{array}$ \\
\hline $7 \%(4)$ & $24 \%(14)$ & $64 \%(38)$ & $2 \%(1)$ & $0 \%(0)$ & $0 \%(0)$ & $3 \%(2)$ \\
\hline
\end{tabular}

Interest in More Information: Would you be interested in learning more about childhood nutrition?

\begin{tabular}{|l|l|l|l|l|l|l|}
\hline Very & Interested & $\begin{array}{l}\text { Somewha } \\
\mathrm{t}\end{array}$ & Little & Not & $\begin{array}{l}\text { Not } \\
\text { sure }\end{array}$ & $\begin{array}{l}\text { No } \\
\text { answer }\end{array}$ \\
\hline $\begin{array}{l}19 \% \\
(11)\end{array}$ & $56 \%(33)$ & $14 \%(5)$ & $5 \%(3)$ & $0 \%(0)$ & $7 \%(4)$ & $0 \%(0)$ \\
\hline
\end{tabular}

Impact: Do you think that nutrition education in schools could positively impact student's eating habits?

\begin{tabular}{|l|l|l|l|l|l|l|}
\hline $\begin{array}{l}\text { Short- } \\
\text { and } \\
\text { longter } \\
\mathrm{m}\end{array}$ & $\begin{array}{l}\text { Yes, only } \\
\text { short-term }\end{array}$ & $\begin{array}{l}\text { Little } \\
\text { impact }\end{array}$ & No impact & $\begin{array}{l}\text { Not } \\
\text { sure }\end{array}$ & $\begin{array}{l}\text { No } \\
\text { answer }\end{array}$ \\
\hline $\begin{array}{l}61 \% \\
(36)\end{array}$ & $15 \%(9)$ & & $17 \%(10)$ & $0 \%(0)$ & $3 \%(2)$ & $0 \%(0)$ \\
\hline
\end{tabular}

Responsibility: Who is responsible for providing nutrition education to children ${ }^{\mathrm{a}}$

\begin{tabular}{|l|l|l|l|l|l|l|}
\hline $\begin{array}{l}\text { Everyo } \\
\text { ne }\end{array}$ & Parents & Teachers & $\begin{array}{l}\text { Governm } \\
\text { ent }\end{array}$ & $\begin{array}{l}\text { Health } \\
\text { Profession } \\
\text { als }\end{array}$ & $\begin{array}{l}\text { Cafet } \\
\text { eria } \\
\text { Perso } \\
\text { nnel }\end{array}$ & Others \\
\hline $\begin{array}{l}73 \% \\
(43)\end{array}$ & $22 \%(13)$ & $10 \%(6)$ & $3 \%(2)$ & $12 \%(6)$ & $\begin{array}{l}10 \% \\
(6)\end{array}$ & $0 \%(0)$ \\
\hline
\end{tabular}

Do you think that the school cafeteria should be involved in a successful nutrition education curriculum?

\begin{tabular}{|l|l|l|l|l|l|l|}
\hline Yes & & & & No & $\begin{array}{l}\text { Not } \\
\text { sure }\end{array}$ & $\begin{array}{l}\text { No } \\
\text { answer }\end{array}$ \\
\hline $\begin{array}{l}76 \% \\
(45)\end{array}$ & & & & $7 \%(4)$ & $\begin{array}{l}12 \% \\
(7)\end{array}$ & $3 \%(2)$ \\
\hline
\end{tabular}

Table 3: Facilitators of SFP for Involvement in Elementary School Nutrition Education $(\mathrm{n}=59)$. ${ }^{\mathrm{a}}$ In contrast to the other questions, participants chose more than one answer.

The greatest barriers for involvement of SFP in elementary school nutrition education were cost $(66 \%)$ and time (58\%; Table 4). Most SFP (75\%) marked at least one of these two barriers on the survey. Lack of time was also perceived as the primary personal barrier (32\%). Lack of time was a greater barrier for managers than employees $(79 \%$ versus $39 \%$ for barrier at school: $\mathrm{P}=0.003 ; 57 \%$ versus $10 \%$ for personal barrier: $\mathrm{P}=0.0002)$. Another important personal barrier was feeling uncomfortable teaching nutrition (34\%), which included respondents that marked either "I don't think I am the right person to teach nutrition" or "I feel uncomfortable teaching". Feeling uncomfortable teaching nutrition was a greater barrier for managers than employees (50\% versus $19 \%$; $\mathrm{P}=0.03$ ). Limited proficiency in nutrition education (27\%) was another important personal barrier. Most SFP (75\%) were interested in nutrition education training. Nutrition education training was not further specified; based on a comment "We would love to have Jamie Oliver come teach the district", there was interest in more culinary training. SFP interested in nutrition education training SFP perceived barriers for participating; the greatest barrier were cost ("only if it is free" or "only if the school district pays for it"), which was marked by 9 of 18 respondents who were interested in training (55\%), and lack of time for training (7 of 18 respondents). Only 26 respondents interested in training reported no barriers (59\%).

\begin{tabular}{|l|l|}
\hline $\begin{array}{l}\text { What are the greatest barriers at school to incorporate the } \\
\text { school cafeteria into a nutrition education curriculum? }\end{array}$ & $\begin{array}{l}\text { Respons } \\
\text { es }^{\mathbf{a}}\end{array}$ \\
\hline No money available & $66 \%(39)$ \\
\hline No time available & $58 \%(34)$ \\
\hline No staff available & $34 \%(20)$ \\
\hline No suitable curriculum & $15 \%(9)$ \\
\hline No support from teachers & $7 \%(4)$ \\
\hline No administrative support & $2 \%(1)$ \\
\hline Others & $0 \%(0)$ \\
\hline Did not answer & $3 \%(2)$ \\
\hline What are your greatest personal barriers for participating in & $\begin{array}{l}\text { Respons } \\
\text { es }\end{array}$ \\
\hline nutrition education? & $32 \%(19)$ \\
\hline I don't have time & $27 \%(16)$ \\
\hline I don't have enough nutrition education & $22 \%(13)$ \\
\hline I don't think l'm the right person to teach nutrition & $17 \%(10)$ \\
\hline I feel uncomfortable teaching & $7 \%(4)$ \\
\hline It is not my responsibility & \begin{tabular}{l} 
a \\
\hline
\end{tabular} \\
\hline
\end{tabular}


Page 5 of 8

\begin{tabular}{|c|c|}
\hline $\begin{array}{l}\text { Others [students don't want healthy food }(n=1) \text { and lack of funding } \\
(n=1)]\end{array}$ & $3 \%(2)$ \\
\hline No barrier & $15 \%(9)$ \\
\hline Did not answer & $8 \%(5)$ \\
\hline Would you be interested in nutrition education training? & $\begin{array}{l}\text { Respons } \\
\text { es }^{\mathrm{a}}\end{array}$ \\
\hline Yes & $75 \%(44)$ \\
\hline Yes, without ifs & $44 \%(26)$ \\
\hline Only if it is free & $12 \%(7)$ \\
\hline Only if it is useful & $12 \%(7)$ \\
\hline Only if I have time & $12 \%(7)$ \\
\hline Only if the school district pays & $7 \%(4)$ \\
\hline Only if my supervisor supports it & $3 \%(2)$ \\
\hline Not sure & $17 \%(10)$ \\
\hline No & $7 \%(4)$ \\
\hline Did not answer & $2 \%(1)$ \\
\hline
\end{tabular}

Table 4: Barriers of SFP for Involvement in Elementary School

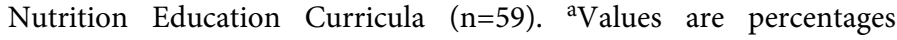
followed by number of observations in parenthesis. Participants could choose more than one answer.

The SFP wanted to be involved in elementary school nutrition education primarily through nutrition posters in the cafeteria (58\%) and new recipes and food items (56\%; Table 5). Under 'Others', SFP noted that they would like to "offer healthy meals with lots of fruits and vegetables". SFP were less interested in oral teaching methods including giving talks in the classroom (36\%) and teaching cooking classes (15\%). Cafeteria personnel noted that "food label stickers" would not work because "food is not individually wrapped for sticker application".

\begin{tabular}{|c|c|}
\hline $\begin{array}{l}\text { In your opinion how should the school cafeteria be involved in } \\
\text { nutrition education? }\end{array}$ & $\begin{array}{l}\text { Respons } \\
\text { es }^{\mathrm{a}}\end{array}$ \\
\hline Nutrition posters & $58 \%(34)$ \\
\hline Offer new recipes/food items & $56 \%(33)$ \\
\hline Talks in classroom & $36 \%(21)$ \\
\hline Food label stickers (green, yellow, red) & $20 \%(12)$ \\
\hline Cooking classes & $15 \%(9)$ \\
\hline $\begin{array}{l}\text { Others [we are already involved }(n=3) \text {, offer healthy meals with lots } \\
\text { of fruits and vegetables }(n=2) \text {, the food we put out }(n=1) \text {, bring back } \\
\text { home-economics }(n=1) \text {, no, kids need more exercise }(n=1) \text {, kids } \\
\text { should know what they are eating }(n=1) \text {, not sure }(n=1) \text { ] }\end{array}$ & $17 \%(10)$ \\
\hline Did not answer & $2 \%(1)$ \\
\hline
\end{tabular}

Table 5: Preferences of SFP for Involvement in Elementary School Nutrition Education $(n=59)$. ${ }^{a}$ Values are percentages followed by number of observations in parenthesis. Participants could choose more than one answer.

\section{Discussion}

\section{School menu survey}

New nutrition policies being implemented starting 2012 document the commitment of federal and state officials to improve students' diets [5] and resulted in improved nutritional quality of school meal options served [17] and consumed [18,19]. Limited resources in money, time, and staff, however, have been barriers to implement those guidelines in U.S. schools [20,21], including Oregon. Not surprisingly, only a small percentage of elementary schools in Oregon offered in 2011 school meals that met the 2012 guidelines. Our results were similar to those of U.S. wide elementary school surveys [22], and indicate a need to provide SFP with sufficient resources to provide students with nutritious meals. More specifically, the results of our food group and nutrient analysis indicate that school meals were low in legumes, fiber, and vitamin $\mathrm{E}$ and high in saturated fat and sodium, which is similar to U.S. wide surveys using quantitative methodology $[22,23]$. The reliance on the salad bar to meet fruit and vegetable guidelines is understandable but may not help to increase fruit and vegetable consumption, as the majority of fruits and vegetables offered at salad and fruit bars are wasted $[7,8]$. One promising approach to improve students' food choices and reduce food waste are experiential learning activities, including food tasting demonstrations/tables and school gardening programs $[24,25]$, as they expose students to a variety of food choices and experiences. Another promising approach is to improve the access, visual appeal, and convenience of healthy food choices; i.e., choice architecture [26,27].

Offering healthy, nutritious meals for children is one of the core public health goals. Providing healthy, nutritious meals that are affordable, convenient, and appealing to elementary school students is a challenge for SFP. Based on our school menu survey, SFP met this challenge by offering menu items that were familiar and popular with children, such as hotdogs, pizza, spaghetti, chicken nuggets, etc. Similar findings have been reported in U.S. wide elementary school surveys [22]. These menu items are not considered as healthful food options by the public, which can explain the negative comments about the food options in the school cafeteria in our previous study [10] and others [28]. Teachers as well as students may not know the difference between a 'healthy' pizza, prepared by SFP with low fat meat and cheese along with a whole wheat crust and spinach in the sauce to meet federal nutrition standards, and a pizza offered by a fast food restaurant. The limited number and type of food options offered at school was similar to those offered at restaurants (i.e., kid's meals) and may limit the sensory and dietary exposure, experiences, and preferences of children. Similar to the School Nutrition Dietary Assessment Study (SNDA) IV [22], we observed that the cafeteria usually offered one lunch option that was healthier. In our and other studies, a common reason for the limited number of healthy options offered by SFP was that "Students don't want healthy" [20,29-31]. However, studies demonstrate various approaches to improve students' food choices in the school cafeteria [32], including providing incentives for choosing healthier food choices [33], increasing the ratio of healthy and unhealthy food choices offered [34,35], and improving the taste and variety of healthy food choices by hiring a chef $[27,36,37]$, which should remain a focus of future studies.

\section{SFP survey}

Nutrition education plays an important role in promoting healthy food choices in elementary school-aged children. Traditionally, 
nutrition is taught by classroom teachers in elementary schools but is generally ineffective in changing dietary behavior. In contrast, nutrition education programs that include a school cafeteria component have shown great promise in improving students' food choices [38-40]. Surprisingly, there is no publication on if and how SFP want to be involved in nutrition education programs. We were excited that $76 \%$ of SFP were interested in becoming involved in nutrition education programs. Reasons for getting involved were the perceived importance of nutrition education, their concern about childhood nutrition, their knowledge about childhood nutrition, and their interest in learning more about childhood nutrition. Most importantly, they expected a positive impact on students' food choices. In summary, SFP were highly motivated to become involved in nutrition education programs.

There were various barriers for SFP to be part of nutrition education programs, the greatest being time and money in our study. An additional budget is required for many nutrition education activities that involve the school cafeteria, as they not only require delivery of information but include activities such as food preparation and tasting. However, those activities are often cost prohibitive because of budget limitations and indicate a need to provide SFP with additional funding to get involved in nutrition education. Furthermore, experiential learning activities require more preparation, clean up time, and equipment than simply delivering nutrition information; as a consequence, additional staff time is needed. Whereas money was universally perceived as major barrier, time was only for managers and supervisors one of the biggest barriers. This may reflect the greater perceived time demands for managers associated with involving the school cafeteria in nutrition education programs. Previous studies reported that a school cafeteria component requires coordination with classroom teachers as well as training, preparation, and delivery of nutrition information [38,41], all of which are primarily the responsibility of managers. Several studies reported that coordination between classroom teachers and SFP is a challenge, as both act as separate entities and have limited time and experience to collaborate with each other $[12,29,31,42]$. There appears to be tension between classroom teachers and SFP, as SFP perceived that classroom teachers were not supportive of efforts of the SFP to provide healthy meals [20,31]. In our recent survey, classroom teachers were highly critical of the food offered in the school cafeteria [10]. Others reported that classroom teachers perceive that SFP are not interested in working with them [12].

SFP, especially managers and supervisors, were concerned that they might become a substitute for a home economics teacher and would have to teach nutrition education classes ("I feel uncomfortable teaching"). One reason for their concern was lack of teaching expertise ("I don't have enough nutrition education"). Unfortunately, we did not ask SFP about their educational background, but other publications noted that teaching training is generally not part of the SFPs educational backgrounds [20,43]. Another reason was lack of perceived responsibility; although SFP felt responsible to participate in nutrition education, SFP did not consider teaching nutrition classes as part of their responsibilities ("I don't think I am the right person to teach nutrition"). Others reported that SFP preferred informal teaching methods, such as giving advice at the foodservice line, point out foods that are considered healthy, or non-verbal communication, such as providing healthy meals [20]. Similarly in our survey, SFP reported "the food we put out" and "offer healthy meals with lots of fruits and vegetables" as means to be involved in nutrition education. When asked about nutrition education training, one person noted
"We would love to have Jamie Oliver come teach the district", indicating an interest in more culinary training rather than learning how to teach, which was similar to others [20]. In summary, SFP were interested in participating in nutrition education but did not want to teach.

There are opportunities to involve the school cafeteria in nutrition education programs. SFP were highly motivated to participate in nutrition education and preferred activities they felt competent about and were in their domain; i.e., displaying nutrition posters in the cafeteria and offering new recipes and food items. There are various intervention methods in the school cafeteria that can improve students' food choices [32], including food marketing and display. Hiring a chef to provide culinary training for SFP ("We would love to have Jamie Oliver come teach the district") showed recently greatest promise [27], and may provide a low cost option for food service districts and could supplement current strengths of districts in dietetics expertise. However, culinary training has its own barriers, as time and money is often not available for training, as reported by us and others [20]. Moreover, culinary training without having the budget to buy healthy food items or time to prepare them, barriers often reported by SFP $[20,29]$, will only add to the frustration of SFP. One option to consider is raising awareness in students and classroom teachers about new recipes and food items. Potential activities to raise awareness are inviting chefs for cooking demonstrations in the school cafeteria combined with tasting tables. Unfortunately, we did not list these options under preferences. An option that was not mentioned by our respondents but by SFP in other studies was to limit menu options that are less nutritious [31,38]. Similar to others [31], SFP were not interested in labeling food items based on their health index; an intervention that had shown a positive impact on food choices in a hospital study [44]. An alternative would be to provide only positive reinforcement by giving attractive names to healthy food choices [45]. SFP shied away of activities that were outside of the school cafeteria and their job responsibilities, which was giving talks in the classroom and teaching cooking classes. Classroom teachers or nutrition specialists have greater expertise in teaching nutrition than SFP and thus are better suited and more motivated to teach nutrition education classes.

Most studies on nutrition programs that target the school food environment have been conducted in the U.S. [32,46,47]. However, the obesigenic, caloric-dense westernized school food environment is an international problem, as the westernized diet spreads around the world. Since food choices are primarily formed in childhood and are difficult to change in adulthood, it is important to get food choices right during the formative school years. The school is a well-suited environment for improving students' food choices, as an increasing number of students consumes most meals at school. Studies in countries with a caloric-dense western food environment other than U.S. also demonstrate that a combination of increased availability, tasting opportunities, and easy access of nutritious and appealing meal and beverage items, including shelf-stable fruit and vegetable items, and limited access to less nutritious, calorie-dense, high sugar- and sodium meal and beverage items at school are most successful in improving students food choices $[38,47,48]$. This can be achieved through restrictive school food policies and governmental assistance for healthy food choices. Such efforts are not without challenges, as stakeholders are concerned about the costs, time, and the restriction of choices associated with such programs [49,50]. However, the costs associated with childhood obesity and it's comorbidities, estimated to be $\$ 14.1$ billion/year in the U.S. [51], explain why restrictive school 
food policies and governmental assistance for healthy food choices are necessary to stop the global obesity epidemic.

\section{Conclusion and Implications}

Nutrition education plays an important role in promoting healthy food choices in elementary school-aged children. Traditionally, nutrition education is taught by classroom teachers in elementary schools but is generally ineffective in changing dietary behavior. There are multiple options whereby the school cafeteria can be involved in nutrition education programs. We conducted two surveys in Oregon elementary schools to examine the potential role of SFP in nutrition education. Our findings are regional; however, the challenges and opportunities for getting SFP involved in nutrition education are similar in other U.S. states and other countries. In our first survey, we examined the nutrient content of the menu options offered at Oregon elementary schools and learned that the majority of meal options consisted of a limited assortment of widely popular kid's meal options that were modified to increase nutrient content. One more nutritious meal options and food items offered at the salad bar played an important role for school menus meeting federal dietary guidelines. In our second survey, we asked SFP in a cross-sectional, anonymous mail survey if and how they would like to be involved in Oregon elementary school nutrition education and learned that SFP were highly motivated to participate in nutrition education but are concerned about the potential time, cost, and teaching commitments associated with it. They preferred activities in the school cafeteria that utilize their strength; i.e., "offer new recipes and food items" and were interested in more culinary training to improve meal options. Thus, renewed focus should be on developing and implementing nutrition programs that involve and target the school cafeteria and provide SFP with opportunities to learn about and offer more and new nutritious, appealing recipes and food items.

\section{References}

1. Lytle LA (1995) Nutrition education for school-aged children. J Nutr Educ 27: 298-311.

2. Food and Nutrition Board, Institute of Medicine (2005) Dietary reference intakes for energy, carbohydrate, fiber, fat, fatty acids, cholesterol, protein, and amino acids. The National Academy Press, Washington, DC.

3. McGuire S (2011) U.S. Department of Agriculture and U.S. Department of Health and Human Services, Dietary Guidelines for Americans, 2010 (7th Edn), Washington, DC: U.S. Government Printing Office, January 2011. Adv Nutr 2: 293-294.

4. Office of the Federal Registrar (1995) School Meals Part 210 National School Lunch Program, 7 CFR part 210.

5. Office of the Federal Registrar (2012) Nutrition Standards in the National School Lunch and School Breakfast Programs, 7 CFR parts 210 and 211.

6. Rhodes D, Clemens J, Goldman J, Lacomb R, Moshfegh A (2015) What we eat in America, NHANES.1-40.

7. Adams MA, Pelletier RL, Zive MM, Sallis JF (2005) Salad bars and fruit and vegetable consumption in elementary schools: a plate waste study. J Am Diet Assoc 105: 1789-1792.

8. Cohen JF, Richardson S, Austin SB, Economos CD, Rimm EB (2013) School lunch waste among middle school students: nutrients consumed and costs. Am J Prev Med 44: 114-121.

9. Frei S, Frei B, Bobe G (2014) Low vitamin D status and inadequate nutrient intakes of elementary school children in a highly educated Pacific Northwest community. J Extension 52: 4RIB2.
10. Perera T, Frei S, Frei B, Wong SS, Bobe G (2015) Improving nutrition education in U.S. elementary schools: challenges and opportunities. J Educ Pract (accepted).

11. Stang J, Story M, Kalina B (1998) Nutrition education in Minnesota public schools: perceptions and practices of teachers. J Nutr Educ 30: 396-404.

12. US Department of Education, National Center for Education Statistics (1996) Nutrition education in public elementary and secondary schools, NCES 96-852, by C. Celebuski and E. Farris. J. Carpenter, project officer. Washington, DC.

13. Garcia-Dominic O, Treviño RP, Echon RM, Mobley C, Block T, et al. (2012) Improving quality of Food Frequency Questionnaire response in low-income Mexican American children. Health Promot Pract 13: 763-771.

14. Hunsberger M, O'Malley J, Block T, Norris JC (2015) Relative validation of Block Kids Food Screener for dietary assessment in children and adolescents. Matern Child Nutr 11: 260-270.

15. Glanz K, Rimer BK, Lewis FM (2002) Health behavior and health education: theory, research, and practice, Jossey Bass (3rd Edn), San Francisco, CA.

16. SAS Institute Inc (2009) SAS/STAT 9.2 User's Guide. SAS Institute Inc, Cary, NC.

17. Bergman EA, Englund T, Taylor KW, Watkins T, Schepman S, et al. (2014) School lunch before and after implementation of the Healthy Hunger-Free Kids Act. J Child Nutr Managem 38: 1-12.

18. Cohen JF, Richardson S, Parker E, Catalano PJ, Rimm EB (2014) Impact of the new U.S. Department of Agriculture school meal standards on food selection, consumption, and waste. Am J Prev Med 46: 388-394.

19. Cullen KW, Chen TA, Dave JM, Jensen H (2015) Differential Improvements in Student Fruit and Vegetable Selection and Consumption in Response to the New National School Lunch Program Regulations: A Pilot Study. J Acad Nutr Diet 115: 743-750.

20. Rida Z (2012) School food environment the frontline for childhood obesity prevention; a mixed-method study of nutritional competences and skills of school nutrition professionals in Nebraska. Ph.D. thesis, University of Nebraska-Lincoln, Lincoln, NE.

21. Thiagarajah K, Getty VM, Johnson HL, Case M, Herr SJ (2015) Methods and challenges related to implementing the new National School Lunch Program regulations in Indiana. J Child Nutr Managem 39: 1-11.

22. U.S Department of Agriculture, Food and Nutrition Service, Office of Research and Analysis (2012) School Nutrition Dietary Assessment Study IV, Vol. I: school foodservice operations, school environments, and meals offered and served, by Fox MK, Condon E, Crepinsek MK, Niland K, Mercury D et al., Project Officer, Fred Lesnett, Alexandria.

23. Crepinsek MK, Gordon AR, McKinney PM, Condon EM, Wilson A (2009) Meals offered and served in US public schools: do they meet nutrient standards? J Am Diet Assoc 109: 31-43.

24. Lakkakula A, Geaghan JP, Wong WP, Zanovec M, Pierce SH, et al. (2011) A cafeteria-based tasting program increased liking of fruits and vegetables by lower, middle and upper elementary school-age children. Appetite 57: 299-302.

25. Berezowitz CK, Bontrager Yoder AB2, Schoeller DA3 (2015) School Gardens Enhance Academic Performance and Dietary Outcomes in Children. J Sch Health 85: 508-518.

26. Hanks AS, Just DR, Smith LE, Wansink B (2012) Healthy convenience: nudging students toward healthier choices in the lunchroom. J Public Health (Oxf) 34: 370-376.

27. Cohen JF, Richardson SA, Cluggish SA, Parker E, Catalano PJ, et al. (2015) Effects of choice architecture and chef-enhanced meals on the selection and consumption of healthier school foods: a randomized clinical trial. JAMA Pediatr 169: 431-437.

28. Bauer KW, Patel A, Prokop LA, Austin SB (2006) Swimming upstream: faculty and staff members from urban middle schools in low-income communities describe their experience implementing nutrition and physical activity initiatives. Prev Chronic Dis 3: A37. 
Citation: Perera T, Frei S, Frei B, Wong SS, Bobe G (2015) The Role of School Foodservice Personnel in Nutrition Education: Challenges and Opportunities at U.S. Elementary Schools. J Health Edu Res Dev 3: 133. doi:10.4172/2380-5439.1000133

Page 8 of 8

29. Cho H, Nadow MZ (2004) Understanding barriers to implementing quality lunch and nutrition education. J Community Health 29: 421-435.

30. Nollen NL, Befort CA, Snow P, Daley CM, Ellerbeck EF, et al. (2007) The school food environment and adolescent obesity: qualitative insights from high school principals and food service personnel. Int J Behav Nutr Phys Act 4: 18.

31. Slawson DL, Southerland J, Lowe EF, Dalton WT 3rd, Pfortmiller DT, et al. (2013) Go Slow Whoa meal patterns: cafeteria staff and teacher perceptions of effectiveness in winning with wellness schools. J Sch Health 83: 485-492.

32. Frerichs L, Brittin J, Sorensen D, Trowbridge MJ, Yaroch AL, et al. (2015) Influence of school architecture and design on healthy eating: a review of the evidence. Am J Public Health 105: 46-57.

33. List JA, Samek AS (2015) The behavioralist as nutritionist: leveraging behavioral economics to improve child food choice and consumption. J Health Econ 39: 135-146.

34. Whitaker RC, Wright JA, Finch AJ, Psaty BM (1993) An environmental intervention to reduce dietary fat in school lunches. Pediatrics 91: 1107-1111.

35. Hakim SM, Meissen G (2013) Increasing consumption of fruits and vegetables in the school cafeteria: the influence of active choice. J Health Care Poor Underserved 24: 145-157.

36. Cohen JF, Smit LA, Parker E, Austin SB, Frazier AL, et al. (2012) Longterm impact of a chef on school lunch consumption: findings from a 2 year pilot study in Boston middle schools. J Acad Nutr Diet 112: 927-933.

37. Just DR, Wansink B, Hanks AS (2014) Chefs move to schools. A pilot examination of how chef-created dishes can increase school lunch participation and fruit and vegetable intake. Appetite 83: 242-247.

38. Rana L, Alvaro R (2010) Applying a Health Promoting Schools approach to nutrition interventions in schools: key factors for success. Health Promot J Austr 21: 106-113.

39. Schetzina KE, Dalton WT, Pfortmiller, DR, Robinson HF, Lowe EF, et al. (2011) The Winning with Wellness pilot project. Rural Appalachian elementary student physical activity and eating behaviors and program implementation 4 years later. Fam Community Health 34: 154-162.

40. Williamson DA, Han H, Johnson WD, Martin CK, Newton RL Jr (2013) Modification of the school cafeteria environment can impact childhood nutrition. Results from the Wise Mind and LA Health studies. Appetite 61: 77-84.
41. Levine E, Olander C, Lefebvre C, Cusick P, Biesiadecki L, et al. (2002) The Team Nutrition pilot study: lessons learned from implementing a comprehensive school-based intervention. J Nutr Educ Behav 34: 109-116.

42. U.S Department of Education, National Center for Education Statistics (2000) Nutrition education in public elementary school classroom, NCES 200-040, by Celebuski C and Farris S (Eds) Burns, project officer. Washington, DC.

43. Merlo CL, Harris CM, Lane KG (2013) Nutrition services and the school nutrition environment: results from the School Health Policies and Practices Study 2012. Chapter 7 in Results from the School Health Policies and Practices Study 2012. Pp.75-89.

44. Thorndike AN, Riis J, Sonnenberg LM, Levy DE (2014) Traffic-light labels and choice architecture: promoting healthy food choices. Am J Prev Med 46: 143-149.

45. Wansink B, Just DR, Payne CR, Klinger MZ (2012) Attractive names sustain increased vegetable intake in schools. Prev Med 55: 330-332.

46. Brown T, Summerbell C (2009) Systematic review of school-based interventions that focus on changing dietary intake and physical activity levels to prevent childhood obesity: an update to the obesity guidance produced by the National Institute for Health and Clinical Excellence. Obes Rev 10: 110-141.

47. Ganann R, Fitzpatrick-Lewis D1, Ciliska D, Peirson LJ, Warren RL, et al. (2014) Enhancing nutritional environments through access to fruit and vegetables in schools and homes among children and youth: a systematic review. BMC Res Notes 7: 422.

48. Lee A1, Ho M, Keung V (2010) Healthy school as an ecological model for prevention of childhood obesity. Res Sports Med 18: 49-61.

49. Downs SM, Farmer A, Quintanilha M, Berry TR, Mager DR, et al. (2012) From paper to practice: barriers to adopting nutrition guidelines in schools. J Nutr Educ Behav 44: 114-122.

50. Middleton G, Keegan R, Henderson H (2012) A qualitative exploration of stakeholder perspectives on a school-based multi-component health promotion nutrition programme. J Hum Nutr Diet 25: 547-556.

51. Pelone F, Specchia ML, Veneziano MA, Capizzi S, Bucci S, et al. (2012) Economic impact of childhood obesity on health systems: a systematic review. Obes Rev 13: 431-440. 